\title{
Biological Variation in Anopheles darlingi Root JD Charlwood
}

\author{
Swiss Tropical Institute, Socinstrasse 57, Basel CH 4002, Switzerland
}

Behavioural variation in the South American malaria vector Anopheles darlingi is described. At the centre of its distribution, in forest areas close to the city of Manaus, Brazil, it is primarily exophagic and exophilic. Mosquitoes from this area are chromosomally diverse. Towards the northern edge of its distribution (in Guyana and Venezuela) it is more endophagic and less diverse chromosomally. Similarly in the south (in the state of Minas Gerais) it is less polymorphic. In this area, however, it is primarily zoophilic and exophagic. Evidence is presented that female wing size may vary between populations. The possibility that this widely distributed species may be a complex could have important implications for future malaria control schemes.

Key words : Anopheles darlingi - biting - host preference - resting - species complex

According to the theory of forest refugia (Haffer $1969,1974)$ the Amazonian rain forest contracted into isolated patches, or refuges, during dry periods in the Pleistocene with secondary intergradiation when the rainfall increased. The fragmentation of the forest would have provided an excellent templet for the occurrence of allopatric differentiation within a species, which may have eventually resulted in speciation. The observed variation within Heliconius (Brown et al. 1974), Drosophila (Spassky et al. 1971), Anolis (Vanzolini \& Williams 1970) as well as birds (Haffer 1969, 1974), mammals (Hershkovitz 1969) and plants (Prance 1974) is regarded as supporting evidence for the refugia hypothesis.

Even if this were not the case, isolation by distance could be important in promoting genetic divergence (Endler 1977) since most species do not have continuously distributed populations and gene flow between clumped demes is normally leptokurtic (because many more individuals move smaller distances than would be expected if they moved at random). Hence, species distributed over broad geographic ranges are more likely to be divided by changes in geomorphology and climate than species with limited ranges. They are also more likely to have greater habitat diversity and are likely to develop clines and subspecies. This is of more than academic interest in insects such as mosquitoes which are vectors of disease, because variations in their biology and behaviour may influence their vectorial capacity (Elliot 1972). Four factors may influence the capacity of an in-

Received 6 January 1995 Accepted 21 March 1996 sect to transmit disease: (1) abundance; (2) contact with man; (3) susceptibility to infection; and (4) longevity (Gillies 1988). Factors which influence human mosquito contact, such as the propensity to enter houses to feed, the host preference and the behaviour after feeding are particularly important.

Apart from a few isolated instances (Arruda et al. 1986, Branquinho et al. 1993) where it occurs Anopheles darlingi Root is the major, or only, vector of human malaria (Forattini 1962, Lourençode-Oliveira et al. 1989). It is largely responsible for the upsurge of malaria in Brazil (Charlwood et al. 1995 a). It has a range that extends from southern Mexico to the south of Brazil (Forattini 1962). This broad range implies a priori that variations in its biology are likely to exist (Giglioli 1956, Rachou 1958, Zimmerman 1992). This paper summarises some of the information concerning An. darlingi and discusses the effect that the insects' behaviour may have on malaria transmission. The role that environmental or genetic factors may have on determining aspects of behaviour are discussed as potential methods of control especially in the relatively isolated settlements such as are often found in newly opened areas of rainforest, where malaria is particularly prevalent.

Abundance and survival - In order for disease transmission to be sustained sufficient numbers of vectors must occur in relatively close proximity to humans. Numbers of adult An. darlingi are often clustered in relatively small areas. This is probably a function of relative distance to breeding sites since abundance is largely dependant on larval ecology. An. darlingi breeds in partially shaded, neutral, unpolluted and relatively still pools of water. In newly opened up areas of rainforest these pools are often man made and are the result of badly made culverts that act as bridges for roads 
whenever a stream is encountered. On the upstream side of such crossings long, snaking lakes are formed that act as year round breeding sites for mosquitoes. Since water is a valuable asset to settlers, houses are often located close to such blocked streams. This reduces the need for long flights by the mosquito which facilitates malaria transmission. Improvement in the construction of drainage ditches, particularly on the smaller dirt roads, could perhaps have a profound effect on malaria transmission. It is also found in pools alongside rivers. Annual population cycles are dependant on a complex series of factors, such as rainfall (Bruyning 1952, Charlwood 1980) or water table (Klein \& Lima 1990, Rozendaal 1992). In many areas peak numbers occur at the end of the rainy season when abundant water remains available and when the likelihood of flushing by excessive rainfall is reduced. In Costa-Marques in Rondônia and on BR 174 between Manaus and Boa Vista there is an associated peak in the number of malaria cases among settlers at these times. For much of the annual cycle $A n$. darlingi populations are very small (Hayes \& Charlwood 1979, Charlwood 1980, Hudson 1984, Rozendaal 1992). This low density makes it difficult to monitor populations even in the absence of control measures.

The problems associated with catching sufficiently large samples has meant that very little work has been performed on survival rate determination of An. darlingi. No substantial information concerning seasonal or geographical variation in survival have been reported, although a greater proportion of potential vectors (i.e. those that were three parous or older) were found during a limited series of dissections from Amazonas (Charlwood 1980) compared to a population from Mato Grosso (Charlwood \& Wilkes 1979). Survival in these populations was age dependant and fitted a Gompertz curve (Clements \& Paterson 1981). In capture-recapture experiments in Rondônia $A n$. darlingi was the most long lived of the local species and the only one caught in any numbers close to the house used in the experiments. All other species, including An. triannulatus and An. oswoldoi, two vectors from other states of Brazil were only caught away from the house close to water (Charlwood \& Alecrim 1988).

Man mosquito contact - Endophiliy - A great deal of interest attaches to the sites of contact between man and vector, largely because of their importance for control by house-spraying. Two factors influence the relative numbers biting indoors and outdoors: reactions to the house itself and the timing of biting activity.

Throughout its range An. darlingi readily enters houses to feed and early observers emphasised its domesticity (Davis 1931, Shannon 1933). In Guyana Giglioli (1948) found that it was the most common anopheline captured inside houses (over 99\%). It was also reported resting inside houses in Surinam by Van der Kuyp (1954) and was reported to be common inside houses in some areas of Brazil, particularly the south (Galvão et al. 1942, Deane et al. 1948). This endophilism contributed to the initial success of the DDT house spraying campaign in Guyana and Venezuela (Giglioli 1951, Gabaldon \& Berti 1954). The resting position within the house is also of obvious importance in assessing the likely effect of insecticides. The preferred resting site within houses appears to differ between areas. In Colombia the majority of females rest within $1 \mathrm{~m}$ of the floor (Quinones \& Suarez 1990) whereas in a study from Acre, Brazil most were collected from the ceiling (Roberts et al. 1987). It is known that the material used in the construction of the house, the number of openings and amount of smoke in the house may affect time spent inside the house and resting site in African anophelines (Gillies \& DeMeillon 1968). This is also likely to be true for South American endophilic anophelines.

In many areas, however readily it enters houses to feed, An. darlingi only spends a few minutes inside. In Surinam, Hudson (1984) estimated that the mosquitoes spent an average of $7.7 \mathrm{~min}$ inside a house before and $17.1 \mathrm{~min}$ after feeding. In Mato Grosso, Brazil, the pre-biting period was approximately 10 min (Charlwood 1980) and Colombia the total time spent inside houses was estimated to be $150 \mathrm{~min}$ (Elliott 1972). In these areas, and also in Minas Gerais, Brazil, females are commonly seen on the exterior walls of houses (Bustamante \& Guedes 1950). Such behaviour has been reported for mosquitoes from areas where the inside walls of houses have been sprayed with DDT (Hayes \& Charlwood 1977, Charlwood \& Paraluppi 1978, Charlwood \& Wilkes 1979, Charlwood 1980). In Surinam Rozendaal (1989) considered that, despite a limited period spent inside houses, indoor spraying with DDT would still provide effective control. Physiological resistance to DDT by An. darlingi has only been reported from a single population from Columbia despite many years of spraying by malaria control programs throughout South America (Suarez et al. 1990). Nevertheless, perhaps because of this heightened exophiliy, control with DDT has not been achieved in many malarious areas. The use of rapid action synthetic pyrethroids has recently been shown to achieve a much greater degree of control (Charlwood et al. 1995a) and shows promise for the future. Selection for an even greater degree of outdoor biting, as occurred in An. farauti from the 
Solomon Islands (Taylor 1975) and An. minimus and An. balabacencis from Thailand (Ishmail et al. 1978) is, however, also a possibility. As pointed out by Gillies (1988) one feature common to both of these instances was a relative lack of alternative hosts in the area. Although cattle are farmed throughout much of An. darlingi's range in many malaria endemic areas alternative hosts are often few and far between.

One factor that will also influence relative endophiliy is the availability of suitable outdoor resting sites. In coastal areas of Guyana suitable outdoor resting sites are uncommon (Giglioli 1956) which may have influenced the success of the indoor spraying campaigns. As with much else concerning its biology, little is known about the outdoor resting sites of An. darlingi. Other members of the subgenus Nyssorhynchus appear to rest in vegetation rather than sites with a solid background. For example, Senoir-White (1951) showed that An. aquasalis in Trinidad rests in tall grasses. The rainforest presumably offers numerous and varied microhabitats suitable for resting mosquitoes.

Feeding patterns - Little is known about the host preference of $A$. darlingi. The choice of host depends on: innate host-specific tendencies, host availability and flight pattern and ecology of the vector (Gillies 1988).

In large cage experiments in Belém, mosquitoes were left overnight with a number of potential hosts including a horse, cow, dog, chicken and human (Deane et al. 1949). The following day blood fed females were collected, squashed and the host identified. Forty-six percent of the mosquitoes had fed on the human; $29 \%$ on the cow and only $13 \%$ on the horse. Obviously the relative sizes of the different hosts would have affected the results. Nevertheless, they indicate an anthropophilic tendency on the part of the mosquito as would be expected from a vector of disease.

Elsewhere the picture is more confused. In spite of a high capture rate off human bait throughout the Amazon A. darlingi has been caught from animals in the open (Charlwood unpubl.). Similarly, although $90.7 \%$ of the anophelines collected inside houses were A. darlingi, Bustamante (1951) and Bustamante et al. (1951) in Bahia and Minas Gerais collected many specimens (34.9\% of the total collected) off animals in the open. More recently comparable figures have been obtained by Oliveira-Ferreira et al. (1992) from paired human and cow or horse collections in a malaria endemic area of Rondônia. In this case An. darlingi accounted for $71.5 \%$ of the anophelines biting a human and $21.5 \%$ biting the animal that was tethered $4 \mathrm{~m}$ distant. When animal baited Shannon dawn traps were used in Minas Gerais it accounted for over $90 \%$ of the anophelines collected (Bustamante et al. 1951). Thus the mosquito in this area appears to be even more zoophilic than elsewhere.

Analysis of the stomach contents of mosquitoes caught resting inside houses also gives variable results. As would be expected, most studies indicated a high degree of anthropophagy (Deane et al. 1948). Brito Mello (in Deane et al. 1948), however, found that only $12 \%$ of their sample had fed on humans and $45 \%$ had fed on a horse. Results such as these are difficult to interpret if information on the relative abundance of the various hosts is not given. Utilization of the Feeding Index, defined as 'the observed proportion of feeds on one host with respect to another divided by the expected comparative proportion of feeds on the two hosts, based on factors affecting feeds' (Kay et al. 1979) would be a useful approach for future studies. This would enable innate, and therefore genetic, factors to be separated from local ecological ones.

Biting cycles - The time of biting by a haematophagous insect is dependant on the interplay between local ecological factors and hereditary endogenous ones. It is perhaps the most thoroughly studied aspect of the biology of An. darlingi. Like many other aspects of its behaviour the peak time of biting and the biting cycle of $A$. darlingi also varies according to location although the effect that this might have on vectorial capacity has largely remained unexplored. Two main patterns have been described. In French Guyana (Pajot et al. 1977), the Mato Grosso, Brazil (Charlwood \& Hayes 1978, Charlwood \& Wilkes 1979), Rondônia (Charlwood \& Alecrim 1988, RosaFreitas et al. 1992) and southeastern Amazonas (Roberts et al. 1987) there is a peak of biting shortly after sunset (with occasional peaks at sunrise) but some biting continues throughout the night. In Amazonas, Roraima (Charlwood \& Hayes 1978, Charlwood 1980) and Surinam (Hudson 1984, Rozendaal 1989) crepuscular activity is not observed. Peak biting activity occurs around midnight in these areas. It has been hypothesised that late biting in mosquitoes may be an adaptation to anthropophagy (Gillies 1988, Charlwood et al. 1995b) since African vectors tend to bite after midnight whereas non-vectors bite in the early evening as they do in Brazil (Charlwood \& Alecrim 1988). It is possible that the form of the biting cycle is dependant on the age of the population, moonphase or distance from the oviposition or mating site. In Colombia and in Costa-Marques, Rondônia, early evening biting was observed during the seasons of peak mosquito numbers (Elliot 1972, Klein \& Lima 1990). At such times a greater proportion of the population are likely to be young insects. The cre- 
puscular peaks observed in An. darlingi in the Mato Grosso consisted largely of nulliparous females (Charlwood \& Wilkes 1979). The repeated observations of relative stable differences between areas, however, indicates that endogenous factors also influence the biting cycle and in Porto Velho, Rondônia age did not affect early evening activity. Heightened crepuscular activity has not, so far, been associated with insecticide avoidance as it was in An. farauti (Taylor 1975).

Little is known about the flight range of $A n$. darlingi. In studies of the vertical distribution $A n$. darlingi was mainly caught at ground level. Twelve percent of the mosquitoes were nevertheless caught in the canopy where they might normally bite monkeys (Deane et al. 1953). Dispersal in mosquitoes is probably as much a function of the environment (including relative abundance of potential hosts and oviposition sites) as it of intrinsic factors. The ability of An. darlingi to search out their victims in the small and remote settlements typical of newly colonized areas of rainforest is an important aspect of malaria transmission and one which we know nothing about. The fact that mini malaria epidemics occur among widely scattered homesteads in rainforest areas indicates that the flight range can be considerable. Insects caught, and marked with fluorescent dusts, close to roadways have been recaptured two (Deane 1947) and seven kilometres from the point of release (Charlwood \& Alecrim 1988). These mosquitoes may represent those that 'miss' locating the proximal host or breeding site and which then have to make prolonged flights due to the scarcity of other hosts or water in the vicinity. Many insects tend to fly close to the edge of high vegetation rather than disperse over the adjacent open ground. In areas of cleared forest it is possible that the mosquitoes track along the edge of the forest margin (Charlwood \& Wilkes 1981) and fly up and down the road. This would enhance contact with humans rather than alternative hosts.

Genetic variation - The identification of genetic polymorphism has been of paramount importance in elucidating relationships in a number of mosquito species. Variations in enzyme frequencies and chromosomes have been described. Narang et al. (1979) and Steiner et al. (1982) described isoenzyme variation in An. darlingi and other members of the subgenus Nyssorhynchus. In all species studied there was a considerable degree of heterozygosity (esterases being more variable than dehydrogenases) and Steiner et al. (1982) based on Nei's genetic distance (D) (Nei 1972) of $\geq 0.59$ between the population from Salvador and four other localities concluded that "genetic evidence provides some support for the idea that sib- ling species complexes exist in the subgenus". This would have obvious implications for malaria transmission.

The first authors to document chromosomal polymorphism in $A n$. darlingi were Guedes et al. (1957) and Schreiber and Guedes (1960, 1961). They described two inversions on one of the autosomes in a population from Bocaiuva, Mato Grosso. In a more extensive study Kreutzer et al. (1972) described nine independent inversions. This number was increased to twelve by Tadei et al. (1982) who examined larval populations from the Manaus-Boa Vista highway close to the centre of distribution of the species. They found a high degree of herterozygosity with inversions distributed on all chromosomes (one on the $\mathrm{X}$, four on $2 \mathrm{R}$, two on $2 \mathrm{~L}$, three on $3 \mathrm{R}$ and two on $2 \mathrm{~L}$ ). Towards the extremes of the species' distribution the number of inversions is smaller and in Araraquara, in the state of São Paulo near the southern border of its distribution, fixation of certain arrangements occurs (Kreutzer et al. 1972). This is similar to the situation described by Da Cunha et al. (1950) and Da Cunha and Dobzhansky (1954) in Drosophila willistoni in which marginal populations exhibit a lesser degree of heterogeneity than those found in the centre of the distribution.

More recently Rosa-Freitas et al. (1992) have examined the relationship between cuticular hydrocarbons, isoenzymes and behaviour, particularly biting behaviour, in three populations of $A n$. darlingi from Costa Marques, in Rondônia, Dourado and Juritiba, located near the type locality in the state of Rio de Janeiro. Although the populations differed in biting time and in the presence of different peaks in cuticular hydrocarbon profile the largest genetic distances between any of the populations was $\leq 0.049$ which is in the range of intra specific variation and the populations did not merit specific status. Nevertheless this is the first work with An. darlingi of the sort undertaken by Coluzzi and co-workers with the An. gambiae Giles group (Coluzzi et al. 1979, 1985, Petraca \& Beier 1992, Touré et al. 1994). The relationship between behavioural and genetic variation awaits further exploration.

Wing size - If observed behavioural differences have a genetic basis it is important to know if there are identifiable morphological characters which may separate different demes. Wing size is a criterion which has been used to differentiate $A n$. triannulatus Neiva \& Pinto and An. triannulatus bachmanni (Forattini 1962). During a series of investigations on the Manaus-Boa Vista highway and Aripuana in Mato Grosso the wing lengths of 82 and180 female An. darlingi collected biting humans was measured. The distance between the 
alula and the wing tip, excluding scales (Fig. 1), was determined using an ocular micrometer on a stereo-dissecting microscope to an accuracy of $0.1 \mathrm{~mm}$. Wing lengths from the two populations are shown in Fig. 2. Using the graphical inflexion method (Lewis \& Taylor 1974) the Aripuana population can be divided into two groups, one of which is similar to the population from Amazonas and the other of which has longer wings. One of the taxonomic features used to identify An. darlingi is that the size of the first costal dark spot, $\mathrm{B}_{1}$, should be at least twice the length of the prehumeral pale spot, $\mathrm{B}_{2}$, (PHP of Rosa-Freitas et al. 1990) (Faran $\&$ Linthicum 1981). The sizes of these spots (Fig.1) were therefore also measured. The relationship between costal spots $B_{1}$ and $B_{2}$ and wing size was similar in both Amazonian and Mato Grosso populations, but whereas the length of $\mathrm{B}_{2}$ changed according to wing length (Fig. 3A) that of the light spot, $\mathrm{B}_{2}$ did not (Fig. 3B). In all cases the dark spot was at least twice the length of the light spot.

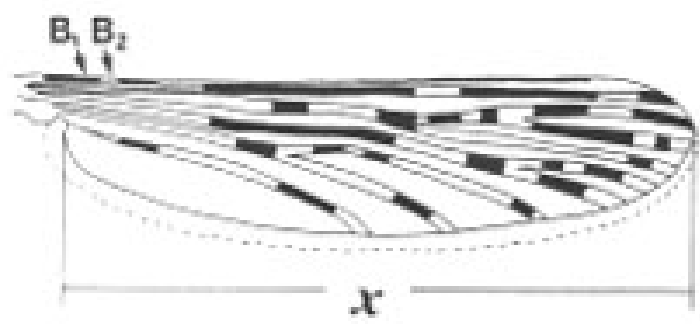

Fig 1 - diagram of Anopheles darlingi wing showing location of costal spots $\mathrm{B}_{1}$ and $\mathrm{B}_{2}$ and $\boldsymbol{x}$, the measured wing length.

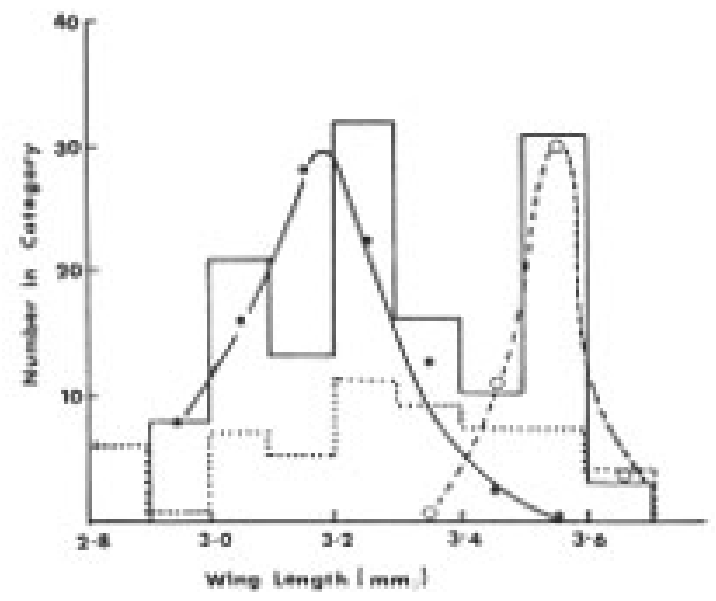

Fig 2 - distribution of wing lengths of Anopheles darlingi females collected biting humans in Amazonas (dotted line) and Mato Grosso, Brazil (solid line). The two curves represent the normal distributions from the Mato Grosso sample using the graphical inflexion method (Lewis \& Taylor 1974).
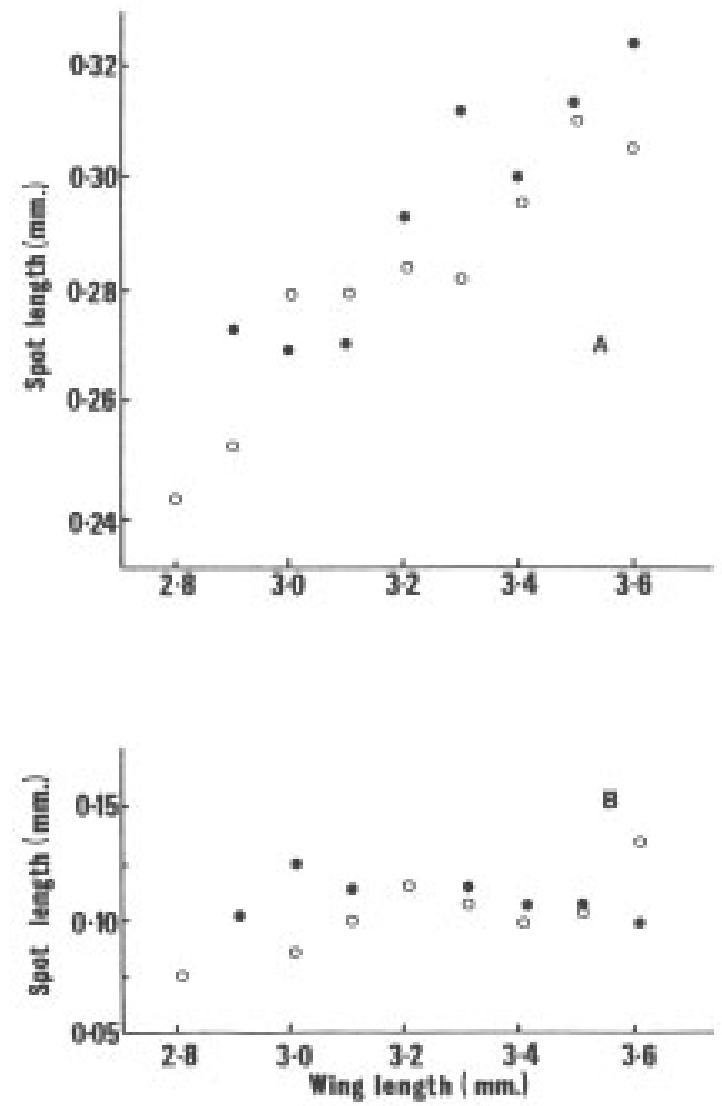

Fig 3 - A: relationship between spot length B1 and wing length. $\mathrm{B}$ : relationship between spot length $\mathrm{B} 2$ and wing length in Anopheles darlingi from Amazonas (open circles) and Mato Grosso (solid circles).

\section{CONCLUSION}

An. darlingi shows a wide range of behavioural variation throughout its distribution. It is a species that is genetically variable. Analysis of other malaria vectors with similar variability, including the similarly distributed An. albitarsus (Rosa-Freitas et al. 1990) has often revealed that what was once considered to be a single species is, in fact, a group of morphologically similar sibling (or cryptic) species each of which differs in their vectorial capacity. The most celebrated examples are $A n$. maculipennis, the Holoarctic malaria vector (Mayr 1963) and An. gambiae from Africa (Frizzi 1952, Davidson 1974, Coluzzi et al. 1979). Studies of the distribution and ecology of these mosquitoes revealed puzzling irregularities similar to those described for An. darlingi. In both cases it was found that the species were actually groups of six (or more) sibling species not all of which are vectors of malaria. Even within species of the $A n$. gambiae complex carriers of different inversion karyotypes differ in their vectorial capacity (Petraca 
\& Beier 1992). Similarly, differences in the salivary gland chromosomes of An. nuneztovari from Brazil and Colombia have been described (Kitzmiller et al. 1973). The vector potential of the two genotypes may differ since An. nuneztovari does not appear to be an important vector in Brazil but is known to be a major vector in Colombia.

Detailed studies involving genetic and morphological analysis of behavioural variants of $A n$. darlingi are required. Uniformity in sampling procedures would assist in the evaluation of geographical comparisons in behaviour. Given the rapid advances in techniques, such as the polymerase chain reaction (PCR) that enable the genotypes of preserved mosquitoes to be determined (Paskewitz \& Collins 1990) it behoves field entomologists to keep their specimens for possible later analysis, even if this was not the primary purpose of their investigation. Genetic analysis of zoophilic and anthropophilic populations would appear to be a good place to start. Whilst it is not certain that different genotypes will differ in their ability to transmit disease, the fact that much of the observed variation in the behaviour of An. darlingi involves parameters important for disease transmission implies that this might be the case. This could affect malaria control operations in South America, particularly in the Amazon basin of Brazil. Whilst such information may not enable more cost effective programs to be devised it may enable appropriate localisation of control operations to be made rendering them more cost effective.

\section{REFERENCES}

Arruda M de, Carvalho MB, Nussensweig RS, Maracic M, Ferreira AW Cochrane AH 1986. Potential vectors of malaria and their different susceptibility to Plasmodium vivax in Northern Brazil identified by immunoassay. Am J Trop Med Hyg 35: 873-881.

Branquinho MS, Taipe Lagos CB, Rocha RM, Natal D, Barata JMS, Cochrane AH, Nardin E, Nussensweig RS, Kloetzal JK 1993. Anophelines in the state of Acre, Brazil, infected with Plasmodium falciparum, $P$. vivax, the variant $P$. vivax VK247 and $P$. malariae. Trans R Soc Trop Med Hyg 87: 391-394.

Brown KS, Turner JRG, Sheppard PM 1974. Quaternary forest refugia in tropical America: Evidence from race formation in Heliconius butterflies. Proc $R$ Soc Series B. 187: 369-378.

Bruyning CFA 1952. Some observations on the distribution of An. darlingi Root in the savanna region of Suriname. Doc Med Geogr Trop 4: 171-174.

Bustamante FM 1951. Efeito das aplicações intradomiciliares de DDT sobre a densidade do Anopheles darlingi em várias regiões do Brasil. Rev Bras Malar 3: 571-590.

Bustamante FM, Guedes AS 1950. Armadilha "Dawn trap" de Shannon. Seu empregro para a captura do A.(N)darlingi em Engenheiro Dolabela, Minas
Gerais. Rev Bras Malar 2:326.

Bustamante FM, Pinto O das, Geledes XSH, Freitas JR 1951. Sobre a captura do Anopheles darlingi e do Anopheles albitarsus nas paredes externas de casas detetizadas em Engenheiro Dolabela, Minas Gerais. Rev Bras Malar 3:122-129.

Charlwood JD 1980. Observations on the bionomics of Anopheles darlingi Root (Diptera: Culicidae) from Amazonas, Brazil. Bull entomol Res 70: 685-692.

Charlwood JD, Alecrim WD 1988. Capture-recapture experiments with Anopheles darlingi in Rondônia, Brazil. Ann Trop Med Parasit 83: 569-576.

Charlwood JD, Hayes J 1978. Variações geográficas no ciclo de picada do Anopheles darlingi Root no Brasil. Acta Amazônica 8: 601-603.

Charlwood JD, Paraluppi ND 1978. Uso de caixas excitorepelentes com Anopheles darlingi Root, A. nuneztovari Gabaldon e Culex pipiens quinquefasciatus Say obtidos em áreas perto de Manaus, Amazonas. Acta Amazônica 8: 605-611.

Charlwood JD, Wilkes TJ 1981. Observations on the biting activity of Anopheles triannulatus bachmanni from the Mato Grosso, Brazil. Acta Amazônica 11: 411-413.

Charlwood JD, Wilkes TJ 1979. Studies on the age-composition of samples of Anopheles darlingi Root (Diptera: Culicidae) in Brazil. Bull entomol Res 69: 337-342.

Charlwood JD, Alecrim WD, Fé N, Mangabeira J, Martins J 1995a. A field trial with Lambda-cyhalothrin (ICON) for the intradomicilliary control of malaria transmitted by Anopheles darlingi Root in Rondônia, Brazil. Acta Tropica 60: 3-13.

Charlwood JD, Smith T, Kihonda J, Billingsley P, Takken W 1995b. Density independent feeding sucess of malaria vectors in Tanzania. Bull entomol Res 85: 29-35.

Clements AN, Paterson GD 1981. The analysis of mortality and survival rates in wild populations of mosquitoes. J appl ecol 18: 373-399.

Coluzzi M, Petraca V, Di Deco MA 1985. Chromosomal inversion intergradation and incipient speciation in Anopheles gambiae. Boll Zool 52: 45-63.

Coluzzi M, Sabatini A, Petraca V, Di Deco MA 1979. Chromosomal differentiation and adaptation to human environment in the Anopheles gambiae complex. Trans R Soc Trop Med Hyg 73: 483-497.

Da Cunha AB, Burla H, Dobzhansky Th 1950. Adaptive chromosomal polymorphism in Drosophila willistoni. Evoluton 4: 212-235.

Da Cunha AB, Dobzhansky Th 1954. A further study of chromosomal polymorphism in Drosophila willistoni in its relation to the environment. Evolution 8: 119-134.

Davidson G 1974. Genetic control of insect pests. Academic Press (London), ix+158 pp.

Davis NC 1931. A note on the malaria-carrying Anophelines in Bélem, Pará and in Natal, Rio Grande do Norte, Brazil. Rev Mal 10: 43-51.

Deane LM 1947. Observações sobre a malária na Amazônia brasileira. Rev Serv Esp Saúde Púb 1:360. 
Deane LM, Causey OR, Deane MP 1948. Notas sobre a distribuição e a biologia dos anofelinos dos regiões Nordestina e Amazônica do Brasil. Rev Serv Esp Saúde Púb 1: 827-966.

Deane LM, Damasceno R, Arouc R 1953. Distribuição vertical de mosquitos em uma floresta dos arredores de Belém, Pará. Fol clin Biol 20: 101-110.

Deane LM, Ferreira-Neto JA, Cerqueira N 1966. Observações preliminares sobre malária de macacos no Estado do Amazonas. Rev Bras Biol 26: 405412.

Deane LM, Vernin CS, Damasceno RC 1949. Avaliação das preferências alimentares das fêmeas de Anopheles darlingi e Anopheles aquasalis em Belém, por meio de provas de precipitina. Rev Serv Esp Saúde Púb 2: 793-808.

Elliott R 1972. The influence of vector behaviour on malaria transmission. Am J Trop Med Hyg 21: 755763.

Endler JA 1977. Geographic variation, speciation and clines. Monographs in Population Biology, No. 10, 295pp.

Faran ME, Linthicum KJ 1981. A handbook of the Amazonian species of Anopheles (Nyssorhynchus) (Diptera: Culicidae). Mosq Syst 13: 1-81.

Forattini OP 1962. Entomologia Medica Vol 1. Faculdade de Higiene e Sáude Publica, São Paulo $622 \mathrm{pp}$.

Frizzi G 1952. Nuovi contributi e prospecttive di recerca nel gruppo Anopheles maculipennis in base allo studio del dimorfismo cromosomico (ordinamento ad $\mathrm{X}$ invertito e tipico) nel messae. Symp Genet 3: 231265.

Gabaldon A, Berti AL 1954. The first large area in the tropical zone to report malaria eradication: Northcentral Venezuala. Am J Trop Med Hyg 3: 793-807.

Galvão ALA, Damasceno RG, Marques AP 1942. Algums observações sobre a biologia dos anofelinos de importância epidemiológica em Belém do Pará. Arq Hig 12: 51-111.

Giglioli G 1948. An investigation of the house-frequenting habits of mosquitoes of the British Guiana coastland in relation to the use of DDT. Am J Trop Med Hyg 28: 43-70.

Giglioli G 1951. Nation-wide malaria eradication projects in the Americas. III Eradication of Anopheles darlingi from the inhabited areas of British Guiana by DDT residual spraying. J Nat Mal Soc 10: 142-161.

Giglioli G 1956. Biological variations in Anopheles darlingi and Anopheles gambiae. Their effect on practical malaria control in the neotropical region. Bull WHO 15: 461-471.

Gillies MT 1988. Anopheline mosquitos: vector behavoiur and bionomics. Chapter 16. In WH Wernsdorfer \& I McGregor (eds). Malaria, Priciples and Practice of Malariology. Churchill Livingstone, Edinburgh.

Gillies MT, DeMeillon B 1968. The anophelinae of Africa south of the Sahara (Ethiopian zoogeographical region). Publications of the South African Institute of Medical Research, Johannesburg, No. 54
Guedes A, Amorim EM, Schreiber G 1957. Análise dos cromosomos salivares em anofelinos brasileiros. Rev Bras Mal Doenças Trop 9: 247-250.

Haffer J 1969. Speciation in Amazonian forest birds. Science 165: 131-137.

Haffer J 1974. Avian speciation in tropical South America, with a systematic study of the toucans (Rhamphastidae) and jacmars (Galbulidae). Pub Nuttal Ornithological Club 14: 370.

Hayes J, Charlwood JD 1977. O Anopheles darlingi evita DDT numa área de malária resistente a drogas. Acta Amazônica 7: 289.

Hayes J, Charlwood JD 1979. Dinâmica estacional de uma população de Anopheles darlingi numa área endêmica de malária no Amazonas. Acta Amazônica 9: 79-86.

Hershkovitz P 1969. The recent mammals of the neotropical region. A zoogeographical and ecological review. $Q$ rev Biol 44:1-70.

Hudson JE 1984. Anopheles darlingi Root (Diptera: Culicidae) in the Suriname rain forest. Bull entomol Res 74: 129-142.

Ishmail IAH, Pininichpongse S, Boorasi P 1978. Responses of Anopheles minimus to DDT residual spraying in a cleared forested foothill area in central Thailand. Acta Tropica 35 : 69-82.

Kay BH, Boreham PFL, Edman JD 1979. Application of the Feeding Index concept to studies of mosquito host-feeding patterns. Mosq News 39: 68-72.

Kitzmiller JB, Kreutzer RD, Tallaferro E 1973. Chromosomal differences in populations of Anopheles nuneztovari. Bull WHO 48: 435-455.

Klein TA, Lima JBP 1990. Seasonal distribution and biting patterns of Anopheles mosquitoes in Costa Marques, Rondônia, Brazil. J Am Mosq Control Assoc 6: 700-707.

Kreutzer RD, Kitzmiller JB, Ferreira E1972. Inversion polymorphism in the salivary gland chromosomes of Anopheles darlingi Root. Mosq News 32: 555565.

Lewis T, Taylor LR 1974. Introduction to experimental ecology. Academic Press (London) xi+401 pp.

Loureço-de-Oliveira R, Guimarães AE, Arle M, da Silva TF, Castro MG, Mottta MA, Deane LM 1989. Anopheline species, some of their habits and relation to malaria in endemic areas of Rondônia State, Amazon region of Brazil. Rev Bras Biol 49: 393397.

Mayr E 1963. Animal species and Evolution. Belknap Press, Harvard, 797 pp.

Narang S, Santos JMM, Garcia JC, Cristakou HD, Narang N 1979. Genética de poulações de anofelinos. IV. Estudos electroforéticos das populações naturais de Anopheles nuneztovari e Anopheles darlingi. Correlação entre espécies. Acta Amazônica 9: 529-542.

Nei M 1972. Genetic distance between populations. Am Nat 106: 283-292.

Oliveira-Ferreira J, Lourenço-de-Oliveira R, Deane LM, Daniel-Ribeiro CT 1992. Feeding preference of Anopheles darlingi in malaria endemic areas of Rondônia State - northwestern Brazil. Mem Inst 
Oswaldo Cruz 87: 601-602.

Pajot F, le Pont F, Molez J, Degallier N 1977. Agressivité d'Anopheles (Nyssorhynchus) darlingi Root, 1926 (Diptera: Culicidae) en Guyane Française. Cahiers ORSTOM ser Ent med et Parasit 15: 15-22.

Paskewitz SM, Collins FH 1990. A method to distinguish mosquitoes of the Anopheles gambiae complex using the polymerase chain reaction. Med Vet Ent 4: 367-373.

Petraca V, Beier JC 1992. Intraspecific chromosomal polymorphism in the Anopheles gambiae complex as a factor affecting malaria transmission in the Kisumu area of Kenya. Am J Trop Med Hyg 46: 229237.

Prance GT 1974. Phytogeographic support for the theory of Pleistocene forset refugia in the Amazon basin based upon evidence from distribution patterns in Caryocaracaeae, Chrysobolanaceae, Dichopetalacae and Lecythidaceae. Acta Amozonica 3: 1-28.

Quinõnes ML, Suarez MF 1990. Indoor resting heights of some anophelines in Columbia. J Am Mosq Control Assoc 6: 602-605.

Rachou RG 1958. Anofelinos do Brasil: Comportamento das espécies vetoras de málaria. Rev Bras Mal 19: 145-181.

Roberts RD, Alecrim WD, Tavares AM, Radke MG 1987. The house frequenting, host seeking and resting behaviour of Anopheles darlingi in southeastern Amazonas, Brazil. J Am Mosq Control Assoc 3: 433-441.

Rosa-Freitas MG, Broomfield G, Priestman A, Milligan PJ, Momen H, Molyneux DH 1992. Cuticular hydrocarbons, isoenzymes and behavior of three populations of Anopheles darlingi from Brazil. J Am Mosq Control Assoc 8: 357-366.

Rosa-Freitas MG, Deane LM, Momen H 1990. A morphological, isoenzymatic and behavioural study of ten populations of Anopheles (Nyssorhynchus) albitarsus Lynch-Arribalzaga, 1878 (Diptera: Culicidae) including from the type locality Baradero, Argentina. Mem Oswaldo Cruz 85: 275289.

Rozendaal JA 1989. Biting and resting behaviour of Anopheles darlingi in the Suriname rainforest. J Am Mosq Control Assoc 5: 351-358.

Rozendaal JA 1992. Relations between Anopheles darlingi breeding habits, rainfall, river level and malaria transmission rates in the rain forest of
Suriname. Med Vet Ent 6: 16-22.

Schreiber G, Guedes AS 1961. Cytological aspects of the taxonomy of anophelines (sub-genus Nyssorhynchus). Bull WHO 24: 657-658.

Senior-White RA 1951. Studies on the bionomics of Anopheles aquasalis Curry, 1932. Part II. Ind J Mal 6: 30-72.

Shannon RC 1933. Anophelines of the Amazon valley. Proc Ent Soc Wash 35: 121-143.

Spassky B, Richmond RC, Perez-Salas S, Pavlovski O, Mourao CA, Hunter AS, Hoeningsberg $\mathrm{H}$, Dobzhansky Th, Ayala FJ 1971. Geography of the sibling species related to Drosophila willistoni and of the semi-species of the Drosophila paulistorum complex. Evolution 25 : 129-143.

Steiner WWM, Narang S, Kitzmiller JB, Swofford DL 1982. Genetic divergence and evolution in Neotropical Anopheles (subgenus Nyssorhynchus), p. 523551. In WWM Steiner, WJ Tabachnick, KS Rai, S Narang (eds). Recent developments in the genetics of insect disease vectors. Stipes publishing, Illinois, USA.

Suarez MF, Quinõnes ML, Palacios JD, Carrillo A 1990. First record of DDT resistance in Anopheles darlingi. J Am Mosq Control Assoc 6: 72-74.

Tadei WP, dos Santos JMM, Rabbani MG 1982. Biologia de anofelinos amazônicos. V. Polimorfismo cromossômico de Anopheles darlingi Root (Diptera, Culicidae). Acta Amazônica 12: 353-369.

Taylor B 1975. Changes in the behaviour of a malaria vector, Anopheles farauti Lav., following use of DDT as a residual spray in houses in the British Solomon Islands Protectorate. Trans R Ent Soc Lond 127: 277-292.

Touré YT, Petraca V, Traore SF, Coulibaly A, Maïga HM, Sankaré O, Sow M, DiDeco MA, Coluzzi M 1994. Ecological genetic studies in the chromosomal form Mopti of Anopheles gambiae s.str. in Mali, West Africa. Genetica 94: 213-223.

Vanzolini PE, Williams EE 1970. South American anoles: The geographic differentiation and evolution of the Anolis chrysolepis species group (Sauria: Iguanidae). Arq Zool SP 19: 1-298.

Van der Kuyp E 1954. Malaria in Nickerie (Surinam). Med geog Trop 7: 259-262.

Zimmerman RH 1992. Ecology of malaria vectors in the Americas and future direction. Mem Inst Oswaldo Cruz 87 Suppl 3: 371-383. 